\title{
ヌードマウス可移植性ヒト腎細胞癌の特性とレクチン染色性
}

\author{
鹿児島大学医学部泌尿器科学教室 (主任 : 大井好忠教授)
}

白 浜 勉 大 井好忠

\section{CHARACTERISTICS OF AN ESTABLISHED HUMAN RENAL CELL CARCINOMA HETEROTRANSPLANTED TO NUDE MICE AND LECTIN BINDING STUDIES}

\author{
Tsutomu Shirahama and Yoshitada Ohi \\ Department of Urology, Faculty of Medicine Kagoshima University
}

(Director: Prof. Y. Ohi)

A primary human renal cell carcinoma has been developed as a xenograft (KDR-1). Passage 5 of KDR-1 strain has histopathologically sustained granular cell type, grade 2 and alveolar type tumor. Electron microscopy revealed the epithelial characteristics of renal cell carcinoma. The doubling time was 6.5 days. The essential histologic characteristics of KDR-1 derived from original tumor has never changed after serial transplantation to nude mice.

Lectin binding affinity of BPA, PNA, DBA UEA-1 and LTA-Ft was investigated using a highly sensitive avidin-biotin peroxidase method. The original and the initial transplant specimens showed strongly positive staining to PNA, but the passage 7 specimen poorly to PNA.

The results indicated that the specific binding site of PNA changed after serial transplantation to nude mice, although the pathological features maintained the characteristics of the original tumor.

要旨：ヌードマウス可移植性ヒト腎細胞癌株（KDR-1）を樹立した。 5 継代目に拈ける組織像は grade 2の顆粒細胞型, 胞巣型であり, 電䫓上も腎細胞癌としての特徵を有していた. doubling time は6.5日で あった. KDR-1株の基本的構造は原腫瘍に類似して打り，継代によっても变化しなかった。

ABC 法を用いて，BPA，PNA，DBA，UEA-1およびLTA-Ft の各レクチンの染色性を検索した。原 腫瘍および初代移植の腫揚組織はPNA に陽性染色を示したが, 染色性は継代とともに減弱し，7 継代目 では痕跡程度の陽性となった。

ヌードマウスに移植継代された腫瘍組織は組織学的には原腫瘍の性質を維持していても, PNA 染色 結果から細胞膜表面の末端糖鎖は変化することが明らかになった。

\section{緒 言}

Rygaard と Povlsen ${ }^{1) 2}$ が報告したヒト癌ヌードマ ウス移植系は今日, 癌研究に欠かせない実験系である。 その主な根拠は，ヒト癌をヌードマウスに移植・継代 しても元の腫瘍の性質がほぼ保たれていることにあ る。これは, 一部のホルモン産生腫湯 ${ }^{334}$ を除き, 形態 学的特徵にもとずく検討の結果である.

今回, ヌードマウス可移植性ヒト腎細胞癌株占を樹 立し，その一般的諸性状ならびに $\mathrm{ABC}$ 法を用いて移 植・継代に伴らレクチン染色性の変化を検討した.

その結果, 形態学的所見のみでは, ヌードマウスに 移植されたヒト癌が元の腫瘍の性質を維持していると
は断定できないと考えられたので報告する。

\section{実験材料および実験方法}

1. ヌードマウス可移植性ヒト腎細胞癌株の樹立 移植原腫瘍には剖検時に得られた54歳男性の胸壁に 浸潤した腫瘍組織を用いた。

臨床経過の概略：昭和58年 5 月 24 日左腎細胞癌の診 断にて左腎摘除術ならびに横隔膜の合併切除術を施行 した。術後, 左腎部〜横隔膜部に ${ }^{60} \mathrm{Co} 6,000 \mathrm{rad}$ 照射 した。

左下肺野に肺転移巣が出現したために同年 9 月 25 日 左肺部分切除術ならびに横隔膜の部分切除を施行し た。しかし, 胸膜から左背部皮下に及ぶ腫瘍の再発を 
みとめ昭和 60 年 12 月 4 日癌性悪液質にて死亡した.

実験動物には $5 \sim 9$ 週齢の $\mathrm{Balb} / \mathrm{c} \mathrm{nu} / \mathrm{nu}$ マウス （日本クレア(株))の雄を用い，飼育は準 specific pathogen free (S.P.F) 条件下で行った.

無菌的に採取した腫瘍を RPMI-1640溶液中で2 3 $\mathrm{mm}^{3}$ 大の腫瘍片に細切しトロッカー針を用いてヌー ドマウスの背部皮下に移植した. 腫瘍移植後, 週 $2 \sim 3$ 回の割合で腫瘍の長径・短径および高さを測定し, 腫 瘍の推定重量（長径 $\times$ 短径 $\times$ 高さ $\div 2$ ）を求めた。

継代移植は腫瘍が一定の大きさ（長径 $20 \mathrm{~mm}$ 以上） に達した時期に無菌的に腫瘍を摘出し初代移植と同様 にヌードマウスへ移植した。

\section{2. 肉眼的 ・病理組織学的検索}

担癌ヌードマウスは剖検し, 腫瘍の肉眼的性状, 周 囲組織への浸潤および遠隔転移の有無を観察した。移 植腫瘍片に隣接する腫瘍組織, 肺, 肝, 心臓, 腎, 脾, 扣よびリンパ節は H.E 染色, 必要に応じて PAS 染色, Alcian-Blue 染色, Sudan III 染色を施行した.

3. 電顕的検索

5 継代目の移植腫瘍の一部をグルタールアルデヒド とオスミウム酸で二重固定し, 型の如くエポン包埋・ 薄切後, 酢酸ウラニールとクェン酸鉛で二重染色を施 し日本電子 JEM 100-B にて観察した。

\section{4. レクチン染色法}

移植原腫瘍および初代，4継代目の各 1 匹 7 継代目 の 5 匹から採取した腫瘍組織の $10 \%$ ホルマリン固定バ ラフィンブロックから得た切片を avidin-biotin peroxidase complex (ABC) 法6)を用いてレクチン染色を 施行した。使用したレクチンは, Bauhinia Purpurea Agglutinin (BPA), Peanut Agglutinin (PNA), Dolichos Biflorus Agglutinin (DBA), Ulex Europaeus Agglutinin (UEA-1), Lotus Tetragonolobus Agglutinin-Ft(LTA-Ft)である. BPA, PNA, DBA, UEA-1怙よびそれらの抗レクチンはE-Y Laboratories 社製, LTA-Ft 招よび抗 LTA-Ft 抗体は当大学 第二生化学教室から供与されたものを使用した。

また，各レクチン濃度は $\mathrm{pH} 7.2,0.01 \mathrm{M} \mathrm{PBS・1 \%}$ bovine serum albumin を用いて，BPA，PNA，DBA および UEA-1は0.004mg/ml, LTA-Ft は0.008mg/ $\mathrm{ml}$ に調整した。

各切片は Fig. 1 のごとく, キシレンで脱パラフィン後 $98 \%$ ×ルアルコールで脱水し, 次に $0.03 \% \mathrm{H}_{2} \mathrm{O}_{2}$ ×チ ルアルコールで室温にて30分反応させ, 内因性ペルオ キシダーゼ反応を阻害した。 pH 7.2，0.01M PBS で
Fig. 1 Staining procedure

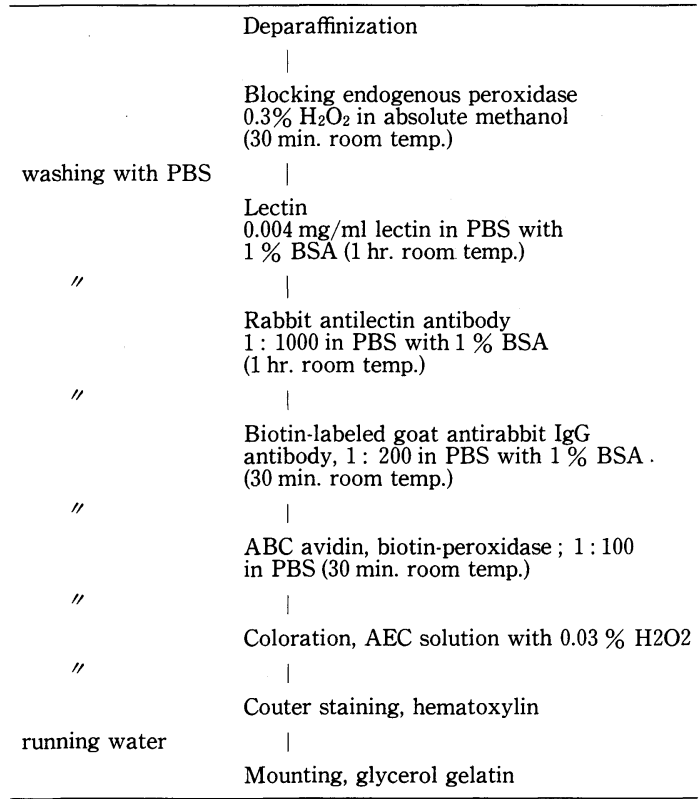

PBS : $0.01 \mathrm{M}$ phosphate buffered saline, $\mathrm{pH} 7.2$

BSA : bovine serum alubumin

AEC : 3-amino-9 ethylcarbazole

$A B C$ : avidin-biotin-peroxidase complex

よく洗浄後, 各レクチンと室温で 1 時間反応させた. PBS 洗浄後, 各ウサギ抗レクチン抗体と室温にて 1 時 間反応させた。

次に PBS 洗浄後, $\mathrm{pH} 7.2,0.01 \mathrm{M}$ PBS 1 $1 \% \mathrm{BSA}$ で $1 ： 200$ に稀釈したビオチン標識ヤギ抗ウサギ IgG 抗体 (original concentration $1.5 \mathrm{mg} / \mathrm{ml}$, Dako immunoglobulins Ltd., Copenhagen, Denmark) と室温 で30分反応させた。

PBS 洗浄後, avidin (original concentration $5 \mathrm{mg}$ / ml, Dako immunoglobulins Ltd., Copenhagen, Denmark), biotin (original concentration $2.5 \mathrm{mg}$ / $\mathrm{ml}$, Dako-immunoglobulins Ltd., Copenhagen, Denmark）の各 $10 \mu \mathrm{g}$ PBS $1 \mathrm{ml}$ に溶解した avidinbiotin peroxidase complex (ABC) を室温にて30分反 応させた。

PBS 洗浄後, 3-amino-ethylcarbazol 液で発色, 蒸留 水で洗浄した後 hematoxylin で核染色を行い glycerol gelatin で封入し鏡検した. 阻害反応は次の通りで ある. BPA は0.2M N-acetyl galactosamine $と 0.2 \mathrm{M}$ D-galactose, PNAは0.2M D-galactose, DBA M acetylgalactosamine, UEA-1および LTA-Ft は 
Fig. 2 Growth curve of KDR-1 strain is demonstrated. The doubling time is 6.5 days.

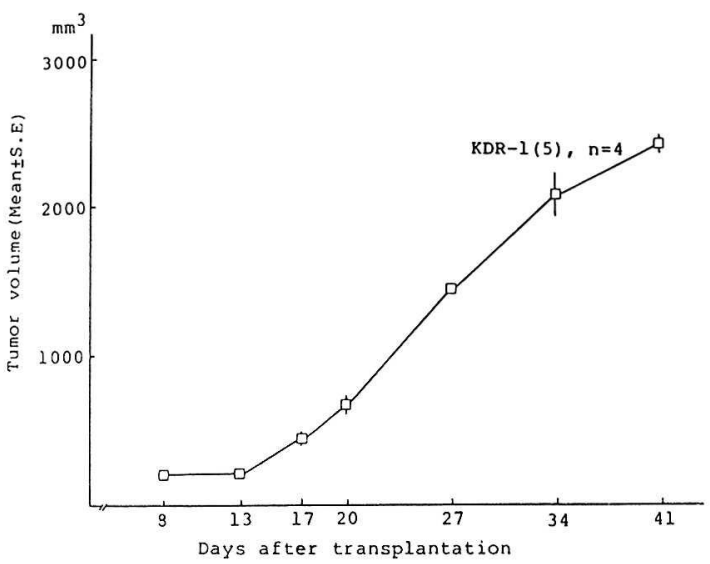

Fig. 3 Some part of the original tumor reveals histologically granular cell type, grade 2 and alveolar type. (H.E. stain, $\times 200$ )

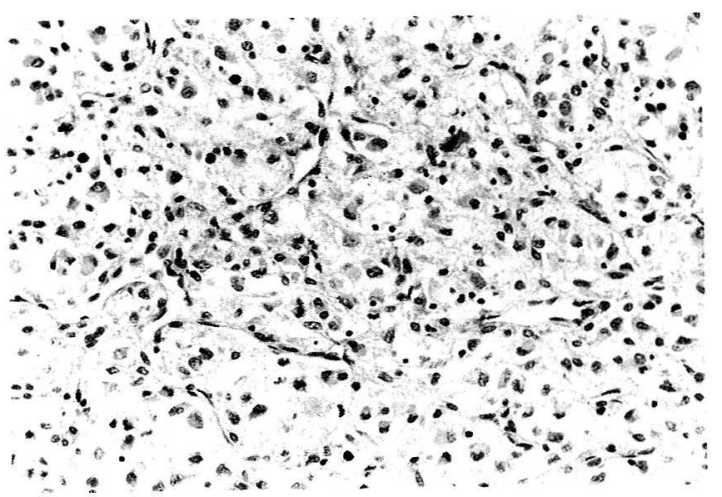

\subsection{L-Fucoseですべて陰性染色を示した.} 実験結果

1. ヌードマウス可移植性ヒト腎細胞癌株の一般的 特性

腎細胞癌株（KDR-1）の 5 継代目に抢ける腫瘍増殖 曲線を Fig. 2 と示す。 doubling timeは6.5日であっ た。現在11継代目に至り，可継代率は $97 \%$ である。移 植原腫場の細胞型は混合型, 紡錐型, 細胞の悪性度は Grade 2, 組織構築は胞巣型, 腺管型, 乳頭型おょび囊 腫型と多彩であったが，Fig. 3 に顆粒細胞型 Grade 2 および胞巣型を示す組織像を提示した，KDR-1株の組 織像は顆粒細胞型, Grade 2拈よび胞巣型7であった。 原腫瘍に比べ細胞間質が広く, 細胞質の空胞変性が目
Fig. 4 Histological features of KDR-1 are similar to the original tumor. However, vacuolization of the cytoplasm increases and the interstitial connective tissue proliferates comparing to the original tumor. (H.E. stain, $\times 200$ )

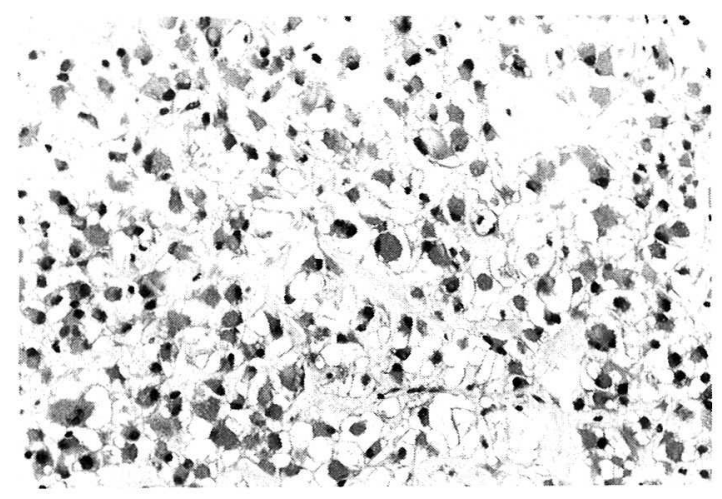

Fig. 5 The plasma membrane forms a brush border like structure (BB). The cytoplasm contains abundant mitochondria $(\mathrm{M})$, glycogen particles (GL) and lipid (L.). ( $\times 13000)$

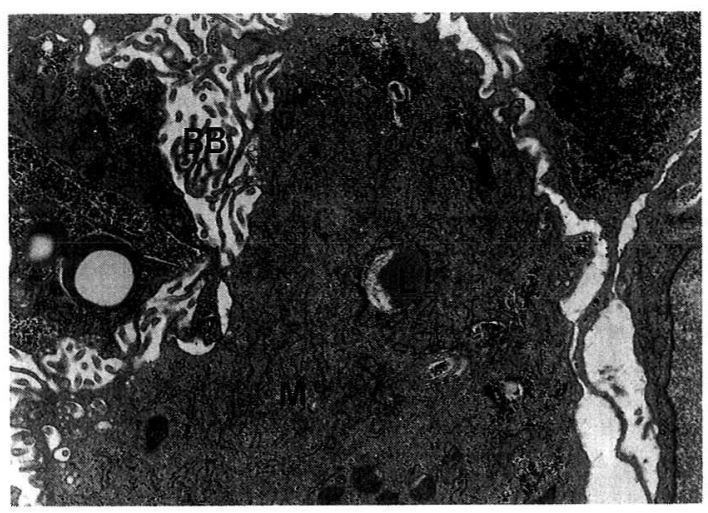

立つ傾向を認めた（Fig. 4). 間質結合織はAlcianBlue 染色にて陽性であり, 酸性粘液多糖体を含んでい ると考光られた。細胞質の PAS 染色陽性物質はジア スターゼで消化されることから，グリコーゲンである ことが判明した。細胞質はSudan III 染色陽性であっ た。電顕上は, 細胞膜は microvilli に冨み, 細胞質内 に多数のグリコーゲン顆粒, 脂肪球掞よびミトコンド リアを認めた（Fig. 5)。尚, 周囲組織への浸潤性発育 や他藏器への転移は認めなかった。

2. レクチン染色

BPA，PNA，DBA，UEA-1拉びLTA-Ft のなか 
Table 1 Lectin staining in the original tumor and KDR-1 strain

\begin{tabular}{l|c|c|c|c}
\hline & $\begin{array}{c}\text { Original } \\
\text { Tumor }\end{array}$ & $\begin{array}{c}\text { Initial } \\
\text { Transaplant }\end{array}$ & $\begin{array}{c}4 \text { th } \\
\text { Passage }\end{array}$ & $\begin{array}{c}7 \text { th } \\
\text { Passage }\end{array}$ \\
\hline BPA & - & - & - & - \\
\hline PNA & $H$ & $H$ & + & $+\sim \pm$ \\
\hline UEA-1 & - & - & - & - \\
\hline LOT-Ft & - & - & - & - \\
\hline DBA & - & $H$ & - & - \\
\hline
\end{tabular}

Staining is graded from + to-

Fig. 6 Binding of PNA to the original tumor is shown. $(\times 200)$ Positive staining on the cytoplasm membrane is prominently observed.

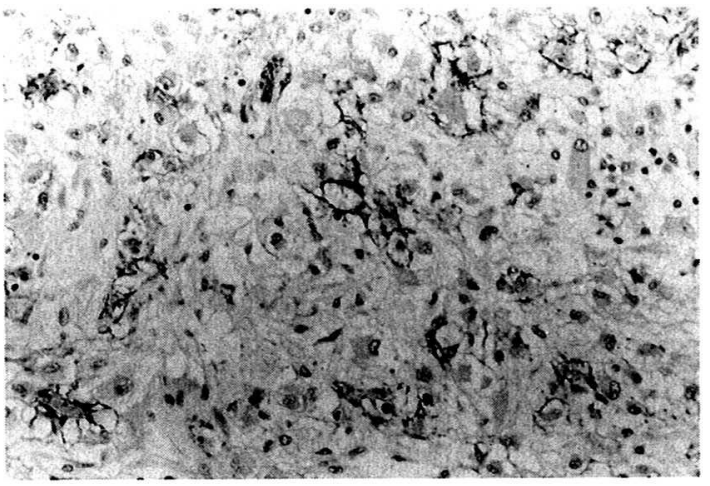

で陽性染色を示したのはPNA とDBA であった。 PNA は原腫瘍組織の顆粒細胞・胞巣型では Table 1, Fig. 6 のように陽性染色部之陰性染色部が同一切片 内に混在したが，細胞膜に強度〜中等度の陽性所見を 認めた。

また，管腔形成を示す細胞集団の内腔面も陽性の染 色像を示した。

初代移植の腫瘍組織では染色性の程度は原腫瘍と同 じであったが，陽性細胞数はわずかに減少した（Fig. 7).

4 継代目では染色性の程度は減弱し, 陽性細胞数も 明らかに減少した。また，管腔内面の細胞膜の陽性染 色像が顕著であった（Fig. 8).

7 継代目の 5 匹中 1 匹では Fig. 9 のように中等度 に染色される細胞を部分的に認めたが，他は痕跡程度 の陽性染色像を認めたにすぎなかった。

DBA は移植原腫瘍では，正常の集合管・遠位尿細管 が陽性に染色されたが，腫瘍部は陰性であった（Fig.
Fig. 7 Binding of PNA to the initial transplant tumor shows the similar pattern to the original tumor. $(\times 200)$

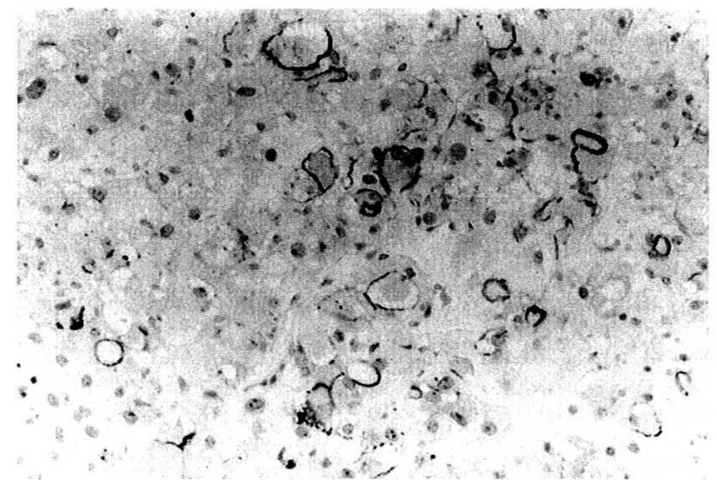

Fig. 8 Binding of PNA to the 4th passage of KDR1 is shown. $(\times 200)$ Cytoplasm faced to the lumen is weakly stained. However, positive stained cells decrease in number.

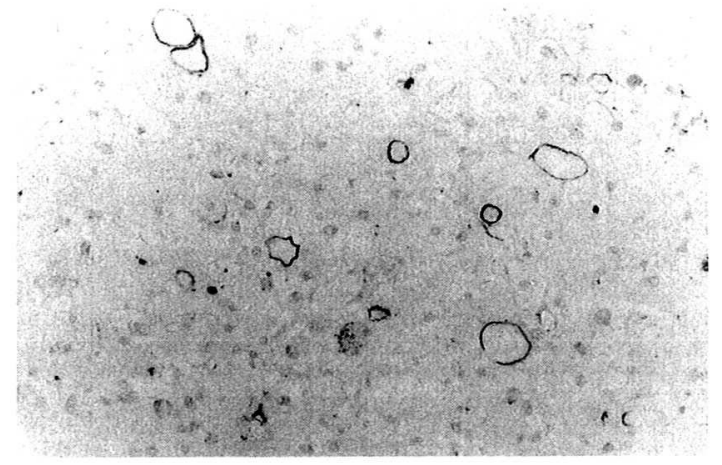

Fig. 9 Figure shows binding of PNA to the 7th passage of KDR-1. $(\times 200)$ The positive staining cells are seen in the localized area.

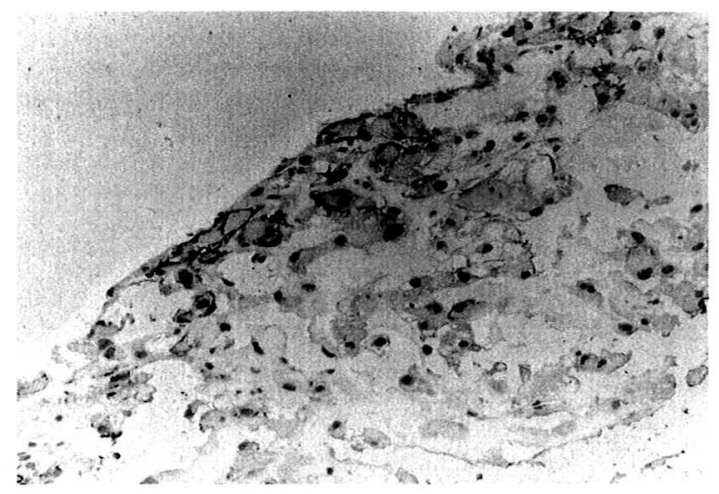


Fig. 10 Binding of DBA to the original tumor is demonstrated. $(\times 200)$ Positive staining is observed in the normal nephron, but no staining is seen in the tumor area.

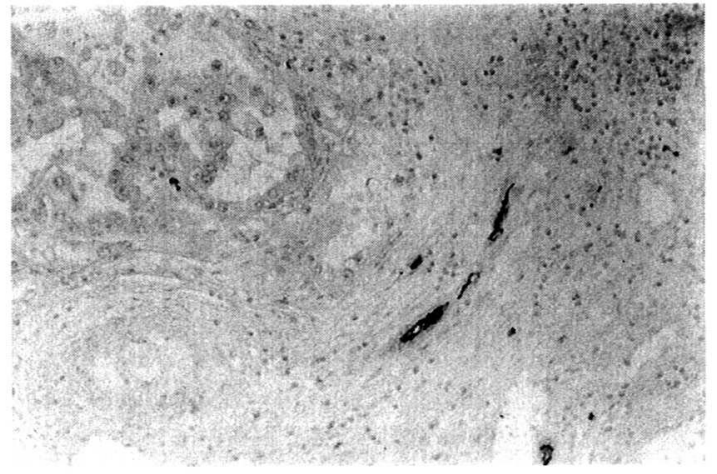

Fig. 11 Binding of DBA to the initial transplant is shown. $(\times 200)$ Some cells show positive staining.

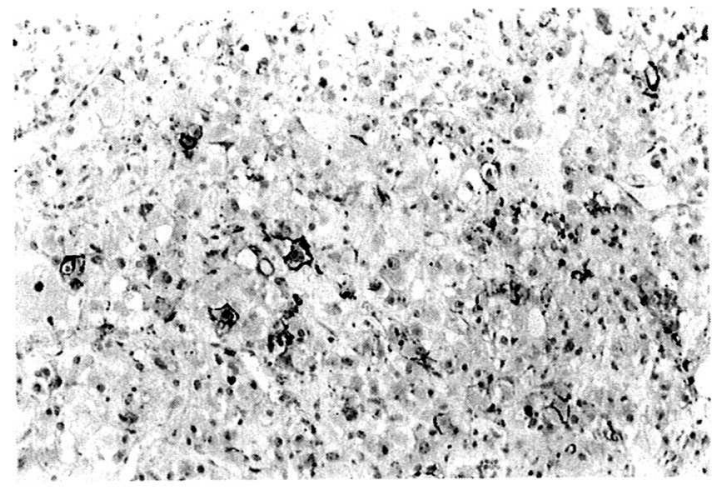

10).

しかし，初代移植では細胞膜は陽性染色像を示し強 度〜中等度に染色される細胞をびまん性に認めた (Fig. 11). 4 継代および 7 継代目では，いずれも陰性 染色であった。

\section{考 察}

移植原腫瘍は細胞型および組織構築上からも多彩な 形態学的特徵を示したが, KDR-1株は顆粒細胞型, Grade 2抢よび胞巣型であった．原腫瘍とやや異なる 点は細胞質の空胞化がより目立ち，間質が広いことで あった。

11継代に至るまで，この基本的構造に変化は認めな かった。 また，特殊染色では細胞質はグリコーゲンお よび脂質に冨み，電顕上は豊富な刷子縁様構造，グリ コーゲン，脂質およびミトコンドリアを認めるなど腎
細胞癌としての特徵89)を有していた. doubling time は6.5日であった。

ヌードマウス・ヒト癌株は形態学的, 機能的特徵(抗 原性, 染色体, 酵素3)あるいはホルモン産生能)）打よ び制癌剂に対する感受性の面からも, 元の腫瘍の性質 を維持していることから, 癌研究にとってすぐれた実 験系である。

しかしながら，継代中に未分化な細胞が優位になっ たり，ホルモン産生能の消失すなわちクローンの選 択・脱落 ${ }^{10)}$ が括こることも事実である。このクローンの 選択・脱落については, ホルモン産生腫瘍を除けば, 組織学的検討のみでは確証が得られないことが多い.

また, ヌードマウス・ヒト癌系は癌特異的免疫・化 学療法および診断学に招いても有用な in vivo 実験系 として期待されるが，そのためには腫場組織をヌード マウスに移植・継代しても, 癌細胞のもつ抗原性が失 われないという前提が必要になる。

文献上, PNA あるいはヒト腎細胞癌由来マウスモ ノクローナル抗体がヌードマウスヒト癌株でも維持さ れるといら報告 ${ }^{1112)}$ はあるが，継代に伴う変化は系統 的に検討されてはいない。

そこで, PAP 法よりもさらに鋭敏である ABC 法を 用いて，移植継代に伴らレクチン染色性の変化を免度 組織化学的に検討した。尚, 凍結切片とホルマリン固 定ではレクチン染色性に差は認められないので13)，今 回はホルマリン固定切片を用いた。

BPA，PNA，DBA，UEA-1およびLTA-Ft の諸種 レクチンのなかで陽性染色像が認められたのはPNA とDBA であった。

D-galactose と特異的に結合する PNA $^{14)}$ は，継代に 伴い陽性に染色される細胞数は減少し， 7 継代目では いずれも部分的に陽性であるか痕跡程度の陽性となっ た.

これは，初代移植では中等度〜強度に陽性染色を示 す細胞をびまん性に認めたことから，単に移植に伴う 技術的要因のためとは考劣にくい，末端糖鎖のシアル 酸化，PNA が反応する糖蛋白の産生能の消失あるい は細胞自体の淘汰などが可能性として考兄られる。

いずれにしても，継代を繰り返すことによって，組 織学的には变化を認めなくても PNA に結合する細胞 膜表面の末端糖鎖は維持されなくなっていくことが判 明した。

一方，PNA が腎癌細胞の分化度を示す指標となり 得るか否かの結論は得られていない, 従来, $\mathrm{T}$ 
(Thomsen-Friedenreich) 抗原 ${ }^{15)}$ に特異的に結合する PNA は未分化な癌細胞に反応すると考光られてき た。腎細胞癌に抢いても，同様な報告 ${ }^{1116)}$ もあるが十分 に検討されたものではない。

Newman ら ${ }^{17)}$ は蛍光染色法を用いて, ラットの乳腺 上皮細胞は乳腺が成熟するにつれて PNA が陽性にな ることを明らかにした。また，ヒト乳癌組織に拈いて も未分化な癌よりも分化した癌の方が PNA は陽性で あったことから，PNAは乳腺上皮細胞の分化度を示 す良い指標であると結論した。

教室の陳 ${ }^{13)}$ は PAP 法を用いて52例の腎細胞癌組織 を染色した結果, 淡明細胞癌では胞巣型よりも分化し た組織構築である腺管型, 乳頭型および囊腫型の方が PNA の陽性染色率は高いことを明らかにした。また 今回, 提示したように胞巣型の構造の中にも小腺管様 構造が認められ，乙か子管腔内面の細胞膜は陽性染色 像を示した。

腺管構造は物質輸送をするための機能的表現3) と考 えられる。

以上の結果から, 腎細胞癌に打いても PNA は癌細 胞の分化度を示す指標になり得ることが示唆された。

DBA が初代移植の腫瘍組織のみに陽性染色像を示 したことの説明は困難であるが、ヌードマウス・ヒト 癌株に打いてレクチンを用いた系統的解析の報告はな いことから，今後さらに検討していきたい。

\section{まとめ}

1. ヌードマウス可移植性ヒト腎細胞癌株 (KDR-1) を樹立した。組織学的には grade 2 の顆粒細胞型, 胞巣 型であり電顕上も腎細胞癌としての特徵を有してい た。 doubling time は6.5日であった。

2。KDR-1株の基本的構造は原腫瘍に類似して扣り 継代によっても変化しなかった。

3。原腫瘍および初代・継代移植の腫瘍組織のレクチ ン染色性を $\mathrm{ABC}$ 法を用いて検索した。

4。PNA は原腫瘍抢よび初代移植では陽性染色像 を示したが，染色性は継代とともに減弱して 7 継代目 では痕跡程度の陽性になった。

5。DBA は初代移植のみ陽性であった。

6。ヌードマウスに移植継代された腫瘍組織は組織 学的には原腫瘍の性質を維持していても, PNA 染色 結果から細胞膜表面の末端糖鎖は変化することが明ら かになった。

\section{文 献}

1) Rygaard, J. and Povlsen, C.O.: Heterotrans- plantation of a human malignant tumors to "Nude" mice. Acta Pathol. Microbiol. Scand., 77, 758-760, 1969 。

2) Povlsen, C.D., Rygaard, J. and Jacobsen, G.K. : Chemotherapy of human malignant melanoma transplanted in the nude mice. Cancer Res., 35 , 2790-2796, 1975.

3) Hagiwara, M., Chen, I., McGonigle, R., Beckman, B., Kasen, F.H. and Fisher, J.W.: Erythropoietin production in a primary culture of human renal carcinoma cell mainatined in the nude mice. Blood, 63, 828-835, 1984 .

4) Kameya, T., Shimosato, Y., Hayashi, H. and Tsumura, M.: Growth and differentiation of hormon producing human tumors in nude mice. proceedings of the second international workshop on nude mice. University of Tokyo Press, Tokyo, 405-416, 1977.

5）白浜 勉, 高尾尊身, 前之原茂穂, 島津久明, 大井 好忠：ヌードマウス可移植性ヒト腎細胞癌に対す るインターフェロンの抗腫瘍効果。医学の歩み, 140, 471-472, 1987 。

6) Hsu, S.M., Raine, L. and Fanger, H.: Use of avidin-biotin peroxidase complex $(\mathrm{ABC})$ in immunoperoxidase techniques: A comparison between $\mathrm{ABC}$ and unlabeled antibody (PAP) procedures. J. Histochem. Cytochem., 29, 577 $-580,1981$.

7) 日本泌尿器科学会・日本病理学会・日本医学放射線 学会編：腎癌取扱い規約. 第一版. 68-85, 金原出 版株式会社, 東京, 1983.

8) Seljelid, R. and Ericsson, J.L.E.: Electron microscopic observations on specializations of the cell surface in renal clear cell carcinoma. Laboratory Investigation, 14, 435-447, 1965.

9) Obering, C., Riviere, M. and Haguenau, F.: Ultrastructure of the clear cells in renal carcinomas and its importance for the demonstration of their renal origin. Nature, 186, 402-403, 1960 .

10）岡田謙一郎, 吉田 修: 尿路悪性腫瘍のヌードマ ウス異種移植の研究。泌尿紀要, 30, 1749-1767, 1984 。

11) Radeler, A., Boehle, A., Otto, U. and Raedler, E. : Differences of glycoconjugates exposed on hypernephroma and normal kidney cells. J. Urol., 128, 1109-1113, 1982 。

12) Fleishmann, J., Heston, W.D.W., Bander, N.H., Bauer, W.C., janney, C., Ratliff, T.L. and Fair, W.R.: Human renal cell carcinoma xenograft: Morphology, growth and chemosensitivity. J. Urol., 134, 570-574, 1985 。 
13）陳 英輝：腎癌のレクチンによる糖組織化学的研 究. 日泌尿会誌, 77, 1405-1415， 1986.

14) Kaifu, R. and Osawa, T.: Synthesis of O- $\beta$-Dgalactopyranosyl

- (1-3) - O - (2- acetamido - 2 - deoxy - $\alpha$ (and $\beta$ )-D-galactopyranosyl)-N-tosyl-L-serine and their interaction with D-galactose binding lectins. Carbohydrate. Res., 69, 78-88, 1979.

15) Klein, P.J., Newman, R.A., Müller, P., Uhlenbruck, G., Citoler, P., Schaefer, H.E., Lennartz, K.J. and Fisher, R.: The presence and significance of the thomsen-friedenreich antigen in mammary gland. J. Cancer Res. Clin. oncol., 93, 205-214, 1979.
16）飯泉達夫, 矢崎恒忠, 加納勝利, 小磯謙吉, 小山哲 夫, 東条克夫: 腎細胞癌の免疫組織化学的研究. 第 2 編。腎癌細胞の細胞膜楉鎖ならびに近位尿細管 上皮抗原に関する研究. 日泌尿会誌, 77, 886-895, 1986.

17) Newman, R.A., Klein, P.J. and Rubland, P.S. : Binding of peanut lectin to breast epithelium, human carcinomas and a cultured rat mammar$y$ stem cell : Use of the lectin as a marker of mammary differentiation. J.N.C.I., 63, 1339 -1346, 1979.

（1987年 9 月 1 日受理） 